TETFLE TEACHER EDCCATON THROUGH FLEXIBLE LEARNING IN AFRICA

JOURNAL
Official publication of the Unit for Distance Education

Faculty of Education

University of Pretoria

Web address: https://upjournals.up.ac.za/index.php/tetfle

Email address: tetflemanager@up.ac.za

\title{
Level of Incorporation of Environmental Awareness into Skill Acquisition Programmes in Lagos, Nigeria
}

Tewo V Bakare

Department of Adult Education, University of Lagos, Nigeria

ISSN: 2788-6298

DOI: https://doi.org/10.35293/tetfle.v2i1.88

\begin{abstract}
Skill acquisition is a growing concern in Nigeria due to socio-economic circumstances and a glut in the labour market which predisposes people to alternatives such as self-employment and a refocus on the care for the environment. Diverse by-products of the self-employed artisans have varied effects on the environment, hence the need to establish how their training affects their environmental practices. The study is a descriptive survey of learners and facilitators in five skill set areas from different skill acquisition programmes in Lagos. The research set out to document the nature of waste output and level of environmental awareness of the participants and facilitators, as well as the effect of training on environmental practices. The study was premised on Botha and Atkins' (2005) theory of adoption of innovation. Three research questions on artisans' typical output, disposal practices, and effect on the environment, along with the influence of facilitators' training guided the study. A total of 250 participants were selected using stratified and proportionate random sampling techniques. The Questionnaire, Key Informant Interview sessions, and Observation Schedule were used for data collection and analysed quantitatively and qualitatively using descriptive statistics and content analysis. Findings revealed a low level of incorporation of environmental awareness into skill training programmes and the gap in teacher training. It was recommended that both adult learners and facilitators be appropriately trained and equipped to effectively tackle $21^{\text {st }}$-century problems.
\end{abstract}

Keywords: Environment, Method, facilitators, skill acquisition, $21^{\text {st }}$ century, Artisans, waste output. 
Volume 2, 2020

\section{Introduction}

The $21^{\text {st }}$-century has emerged with its attendant and peculiar challenges, one of those being the care and management of the environment in a manner that will be sustainable for future generations. Adult education practices have made it patently clear that human actions, as they affect the environment, pose a definite challenge for everyone, and to be engaged in activities that will improve the environment (Bakare, 2018). According to the Great Schools Partnership for $21^{\text {st }}$ Century Skills (2016), environmental literacy is critical, especially in the demonstration of knowledge and understanding of the environment and the circumstances and conditions affecting it, particularly as relates to air, climate, land, food, energy, water and ecosystems. One of the skills associated with the $21^{\text {st }}$ century is the knowledge of environmental and conservation literacy, as well as ecosystems understanding, hinged on the belief that learners must learn what is relevant, useful and in-demand. If this is applied to adult learners, then learning to care for their environment must be prioritised. Thus, when the skill acquisition process is infused with the necessary awareness and action needed, it will make it easier for recipients to adopt and embrace better management of their environment. Brendia (2002) agrees that environmental adult education will be beneficial to adult learners, while Opara and Ogudu (2009) examined the negative effect that farming practices have on the environment. Kumar (2018) equally agrees on the necessity to address the problem from the perspective of e-waste as an emerging threat to the environment. Bakare (op cit) further observed that to maintain the delicate balance between human beings and their physical environment, Nigeria must ensure adequate environmental education. Unfortunately, this has not been conscientiously adhered to, and the effect has been overall environmental degradation. Facilitators and learners in the process of education constitute a viable resource target group for better environmental management to occur. (Those who help adults to learn are referenced facilitators in lieu of teachers).

Skill acquisition is the process of learning and attaining new professional skills, equivalent to artisanship. It could also be a new way of doing old things in order to become proficient in that old skill; this is done through training or experience, according to Feshchuk (2018). It involves a specific form of learning or training for a particular task until a suitable level of expertise is attained on that skill. The action thus becomes automatic, efficient, and almost without conscious thought as the transition between the learned actions becomes smoother, more seamless, and faster. The skills can be repairing, improving computer technology, developing artistic skills, or languages. Most skills are not automatic and are usually learned, deliberately practised, and honed to expertise over a period of time and is a constant process (Feshchuk, op cit). Skill acquisition is, however, now key to survival as a $21^{\text {st }}$-century phenomenon and, in true adult education fashion, it is never too late to learn a skill. Possessing a skill for the adult ensures a means to wealth, selfreliance, independence, job acquisition, and empowerment.

CONTACT: Tewo V Bakare tbakare@unilag.edu.ng

This work is licensed under a Creative Commons Attribution 4.0 International License. 
Eheazu (2016a) maintains that the human environment is made up of all the external factors and forces with which individuals interact from conception to the grave. People interact with the environment daily, and their actions or inactions seriously impact the nature of the environment and it is important that they care for it. Every human action has repercussions for the environment. In this age where environmental awareness is becoming vital to sustainable development, it is imperative to ensure that skill acquisition appropriately considers the effect of what is being learned about the environment and ultimately national development.

Since adults learn for immediate use (Knowles 1985), they can have a direct and immediate impact on the environment as a result of their activities. It is within the framework of adult education that artisans can be exposed to the necessary tools to empower them to care for the environment by making artisans aware of their actions and consequences so they can make informed choices. Facilitators who help adults are instrumental to adult learning. It is thus essential for them to constantly update their knowledge of working with adults to the level of $21^{\text {st }}$ century functionality.

\section{Statement of the Problem}

Skill acquisition is becoming popular as more people are embracing it as a $21^{\text {st }}$-century necessity, so there is the need to pay more attention to it and address any issues concerning it. However, studies on skilled workers' awareness of input and their waste output in the environment are not common. Artisans may not be as aware of environmental protection as they ought to be and practical solutions are seldom promoted in Environmental Education for adults, which will influence adoption patterns. If learners graduated without awareness of their impact on the environment, the ignorance might prevent them from treating their environment differently, hence the need to ensure environmental awareness within programs, and explore facilitators' level of involvement in environmental education. If facilitators do not engage in environmental education or use appropriate methods, the artisans' involvement with the environment will not change, and the environment will continue to suffer. The European Centre for Development of Vocational Training (CEDEFOP, 2012) noted that the economic crisis in the European economy has mandated changes and necessitated new strategies to get people employed more viably, especially in 'green' jobs that encourage eco-friendly production and consumption. Their findings call for further research into education and training requirements that favour the environment.

CONTACT: Tewo V Bakare tbakare@unilag.edu.ng

This work is licensed under a Creative Commons Attribution 4.0 International License. 


\section{Purpose of the Study}

The purpose of this study was to ascertain the level of awareness of learners about their interaction with the environment, and facilitators on the effect of method of handling the training for skill acquisition to note whether consideration for the environment was incorporated. It is to further ascertain that in the $21^{\text {st }}$-century, facilitators and learners imbibe the spirit of resolving current problems concerning the environment, such that both parties are equipped to respond more positively to environmental issues. It is to further test the level of adoption of better environmental practices as a result of the artisans' training. Specifically, the purpose of this study is to establish the level of awareness of artisans about the effect of their waste output on the environment, document the level of incorporation of environmental consciousness into their training and their level of adoption, as well as establish how solutions could be gained through adult education.

\section{Research Questions}

The following research questions guided the study.

1. What are the respondents' typical outputs, mode of disposal, and effect on the environment?

2. What are facilitators' training background and their level of incorporation of environmental awareness into skill acquisition programmes in Lagos state?

3. Do recipients of skill acquisition programs become more aware of their interaction with their environment as a result of their training and method used?

\section{Review of Literature}

The socio-economic situation in Nigeria today mandates the possession of skills, even beyond academic theoretical learning for survival. Many graduates have failed to secure employment, as formal education and certificates no longer guarantee entry into the labour market, and graduates have failed to secure 'white-collar' jobs even in their fields, despite their qualifications. The socioeconomic trend of overdependence on job-seeking in the shrinking world of work emphasises that only skilled people will survive in the future. Different forms of Adult Education have thus waded into the gap to provide people with the necessary tools to survive, cope, and fit into society (Bakare, 2013). The pertinent question is whether skill acquisition programmes are taking the environment into consideration in their practices. Agbor (2016) advocates the incorporation of environmental education into teacher education programs in Nigeria.

CONTACT: Tewo V Bakare tbakare@unilag.edu.ng

This work is licensed under a Creative Commons Attribution 4.0 International License. 
Volume 2, 2020

The Nigerian education system, unlike in more developed nations, is yet to be structured to incorporate skill acquisition into the mainstream educational system, rendering graduates illequipped to survive outside the job market. The hitherto half-hearted attempt by authorities to build entrepreneurial skills into tertiary education is yet to yield tangible results. Unfortunately, Nigeria's warped value system had encouraged people to look down on skill acquisition as menial, pursued by the uneducated. Umunna (2018) categorises skills into Vocational and White Collar. It was suggested that informal skill acquisition might not require excessive mental intelligence, while the other category is for educated people. However, the technological age has made online education more accessible through distance education processes to supplement individualised skill acquisition. Nowadays, people learn through technology-driven resources like YouTube, for example, which makes self-training more accessible, as against the conventional method of formal education. Traditionally in Nigeria, skills were acquired through apprenticeship from an already established expert within a pre-arranged time after which the recipient gained their 'freedom' to set up on their own. Different countries have different approaches. One may apprentice under the traditional version of a 'Journeyman' who is often seen as the skilled expert and experienced craftsman (Emms, 2005), who helps to instruct, oversee, correct and support the apprentice, and may or may not be formally certified. Many artisans in Nigeria learn from Vocational Training Centres, whether publicly or privately run, and now use technology to their advantage to acquire skills online. In modern times, the apprentice learns skills on-the-job and the modern journeyman is more of a concept in adult education to indicate the nature of learning which must be pursued vigorously throughout life. King (2007) relays the Kenyan experience, reporting that a wide variety of skills were acquired by low-income earners, through an unofficial fee-paying apprenticeship at the feet of older, often illiterate craftsmen. This mirrors the usual practice in Nigeria also, in addition to the newer influx of educated people into the non-formal sector.

Prior to 2007, Lagos State had three functioning Skills Acquisition Centres, a number that later rose to 17 by the end of 2011, according to the State Government records. Many people have since availed themselves of skill acquisition opportunities by learning different trades under the government's renewed interest in instituting Poverty Alleviation programs to battle unemployment, after several other failed attempts. Other sponsors of skill acquisition programs include NGOs, religious organisations, and philanthropists. Programmes cater to the youth and women of different categories in pursuance of the United Nation's Millennium Development Goals (MDGs). Learners are trained in courses ranging from literacy to aspects of the Beauty Industry, Hotel and Catering, Carpentry, and Textile, among others. Certificates of competency were usually given by the skill acquisition Centre or other Technical Trade regulatory bodies at the end of the training.

CONTACT: Tewo V Bakare tbakare@unilag.edu.ng

This work is licensed under a Creative Commons Attribution 4.0 International License. 
Volume 2, 2020

Eheazu (2016b) noted that some forms of environmental degradation are anthropogenically caused by human activities, where some are by natural causes. Human activities and outputs account for increasing pollution, and sound ecological practices are essential for sustainable development, which is why many now advocate for greener practices, in line with the doctrine of EU 2020 strategies. Solaja, Aliyu, and Omobowale (2015) observe that the care for the environment has become a monumental responsibility among countries in the world in order to achieve sustainable consumption, communities, as well as a sustainable future, and ultimately, the world. Adekeye, Ojo, and Ajayi (2011) found the fallout of welding to be detrimental to the soil as it could inadvertently enter the food chain and pollutions constitute major health risks. Abia, Fomboh, Ntungwe, Abia, Serika, and Ageh (2016) found that barbers and hairdressers in Yaounde were exposed to occupational hazards through their method of waste disposal.

The seriousness attached to environmental protection has mandated governments and other stakeholders to pay more attention to issues concerning the environment and thus devote more effort, finances, and policies into mitigating the problems. A major conduit has been through different forms of adult education. Nigeria has the Federal Environmental Protection Agency (FEPA), and states have corresponding agencies. Lagos State, in addition, has the Lagos State Waste Management Authority (LAWMA) to take care of refuse, but are artisans and entrepreneurs complementing the government's efforts on the environment? Water pollution is also a major global concern for its potentially disastrous consequences for human and environmental health. Most pollution issues in Lagos are from industrial waste; other pollutants are in the form of smell from garbage, sewage, refuse-burning, and traffic emissions. Ukemenam (2014) agrees that pollutants can be man-made or natural. She mentions carbon monoxide as one of the most common pollutants in Lagos as a result of exhaust, and probably generator fumes. She also noted that the concentration was above FEPA-recommended limits in Lagos, compared to World Health Organization standards. Numbero (2019) adds that Lagos' pollution index at 82.49 is deemed high. Contaminants introduced into the natural environment cause instability, disorder, harm, and discomfort to the ecosystem. Pollution affects land, soil, air, and water, with dire consequences for all living things.

Environmental education consists of all forms of knowledge about the environment. It is interested in the acquisition of skills, knowledge, and understanding to help develop appropriate values, attitudes and behaviour towards the environment. UNESCO (1978) saw it as education aimed at producing a citizenry that is knowledgeable concerning the biophysical environment and its associated problems. Environmental Adult Education, on the other hand, is defined by Eheazu (2013) as a process in which adult individuals gain awareness of their environment, acquire knowledge, values and skills, experience and determination which will enable them to act

CONTACT: Tewo V Bakare tbakare@unilag.edu.ng

This work is licensed under a $\underline{\text { Creative Commons Attribution } 4.0 \text { International License. }}$ 
Volume 2, 2020

individually and collectively in harmony with forces and elements that surround them as they emerge in their daily activities for survival.

The Research and Curriculum Development Department of the Industrial Training Fund (2014), while agreeing with improved trainee employability prospects after skill acquisition programs, recommended training needs assessment and constant curriculum review. Bosah (2013), in a bid to encourage environmental consciousness and awareness from youth, examined the input of environmental education to environmental awareness in order to address global and regional environmental concerns and reported a low level of incorporation of environmental education into the syllabus. Eneji, Onoghen, and Acha (2017) adopted the Phi Delta Kappan model of trainingthe-trainers for environmental education. They suggest that, rather than the usual laissez-faire attitude to the environment, believing it is the government's responsibility to take care of it, individuals and groups must equally begin with the self and contribute meaningfully to the care of the environment. They further advocate Environmental Adult Education, using appropriate methods and techniques incorporated into the programme content.

\section{Theoretical framework}

The curiosity about what motivates the adult to learn leads to the exploration of theories. This study explored the method of training of artisans and its effect on their adoption of positive environmental practices. Botha and Atkins' (2005) theory views adoption from a psychological point of view as a process of decision-making by individuals that requires cognition, or their ability to perceive, understand and interact with their environment in an intelligent manner. This translates into the way in which the learners decide to interact with their physical environment will be a value of how they perceive and understand the situation; in other words, their training background. Botha and Atkins (op cit) believe that the individual moves from a state of ignorance to being aware, and that the adoption process itself is influenced by contextual factors and personal characteristics. They note different stages in the adoption of innovation processes which they described in a somewhat cyclical manner that indicates that the contextual and personal factors will dictate whether an idea is adopted, rejected, ignored or becomes a focus of interest. Of particular interest to this study is their Extension Theory which is about changing voluntary behaviour through communication. The theory, however, only concentrates on bringing about behavioural change rather than providing a framework for studying the adoption of innovation, apart from evaluating Extension outcomes. This may be translated into when adults are learning new things, the method used will be critical to their adoption level. If environmental awareness is therefore, not incorporated into their training, they are unlikely to adopt good environmental practices.

CONTACT: Tewo V Bakare tbakare@unilag.edu.ng

This work is licensed under a Creative Commons Attribution 4.0 International License. 
Volume 2, 2020

When applied to the situation of artisans, their ability to interact positively or negatively with their environment will be a product of the type of exposure or training they have, and the method used in their training; thus it can be subsumed that if their training background does not adequately address their environmental awareness level they may not be able to interact intelligently with their environment. Rogers (2003:18) in the same vein, argues that, even though in the diffusion of innovation the message is about a new idea, most people still depend on a subjective evaluation of what peers who are already adopters convey. This suggests that facilitators have a strong influence in the transmission of new ideas, and if the facilitators are already converted themselves, it will be easier to convey the message to the artisans. This study posits that, if the appropriate method is used, it will assist the adult learner's learning outcome. Thus, they need to be sensitised to perceive, understand and intelligently interact with their environment. Therefore, if the training does not incorporate elements that will make them appreciate their commitment to the environment, then it is not likely that their reaction to their environment will be different after training. This has implications for artisans' environmental practices, policy makers, as well as the innovation adoption theory.

\section{Methodology}

The study was a descriptive survey in nature. It covered the Lagos metropolis, documented environmental practices of skilled workers, and established the level of incorporation of environmental consciousness into training programs by facilitators. Five skill set areas Carpentry, Catering, Hairdressing, Mechanic, and Tailoring — from different Skill Acquisition programmes in Lagos were used in the study. Different Skill Acquisition Centres, formal/informal, were utilised. Proportionate stratified sampling technique was used to select 50 respondents from each of the five trades used, along with 50 facilitators, making a total sample size of 300 . Some of the respondents were still in training while some had graduated and were practising their trade. The study cut across government and privately owned Centres. The nature of their waste output also varied according to their trades. The population was all artisans engaged in skilled work and those still in training and all the program facilitators. This study focused more on the informal vocational skills that are more manual, requiring less of excessive mental acumen. There are three Senatorial Districts in Lagos State, the Lagos West (9 wards), East (5 wards), and Central (5 wards). Lagos West, consisting of nine Local Government Areas was used for the study, from where Skill Acquisition Centres were picked and learners and facilitators selected. The instrumentation consisted of the Questionnaire which was used to gather data, supported with Structured Interviews and Observation using a checklist. Post Graduate students in the Department of Adult Education helped with data collection. Respondents who could not complete the Questionnaire were interviewed. The instruments were duly validated by three experts in the Departments of Adult Education and Environmental Sciences. Test-retest was used to establish

CONTACT: Tewo V Bakare tbakare@unilag.edu.ng

This work is licensed under a Creative Commons Attribution 4.0 International License. 
Volume 2, 2020

coefficient values of the Questionnaire and Interview Schedule at 0.81 and 0.76 , respectively to deem the instruments reliable for the study. Data collected were analysed quantitatively and qualitatively using descriptive statistics and content analysis, and the results presented graphically in percentages and through content analysis.

\section{Findings of the Study}

\section{Background biodata of respondents}

The respondents' bio-data, on the overall, revealed that $53(21.2 \%)$ had higher education, 104 $(41.6 \%)$ had the West African School Certificate (WASC), 48 (19.2\%) had Primary School Leaving Certificate (PSLC), 34 (13.6\%) were Primary School drop-outs while 11 (4.4\%) did not have any formal education. The facilitators equally had a varied educational background. Majority 16 (32\%) had the Primary School Leaving Certificate. This was followed by those with the West African Secondary School Leaving Certificate (13 - 26\%); 11 (22\%) were Primary School non-completers, $4(8 \%)$ had Higher Education equivalent, while $6(12 \%)$ had no formal education, or had a more traditional training background. The majority of the artisans, $200(80 \%)$ had their training with the traditional Apprenticeship scheme/Skill Acquisition Centres and 50 (20\%) through more formal education including Vocational Training Centres. Some 135 (54\%) were still in training, while the rest were already on their own. A total of 142 (56.8\%) were male and the rest were female. A breakdown of the gender is shown in figure 1.

CONTACT: Tewo V Bakare tbakare@unilag.edu.ng

This work is licensed under a Creative Commons Attribution 4.0 International License. 
Volume 2, 2020

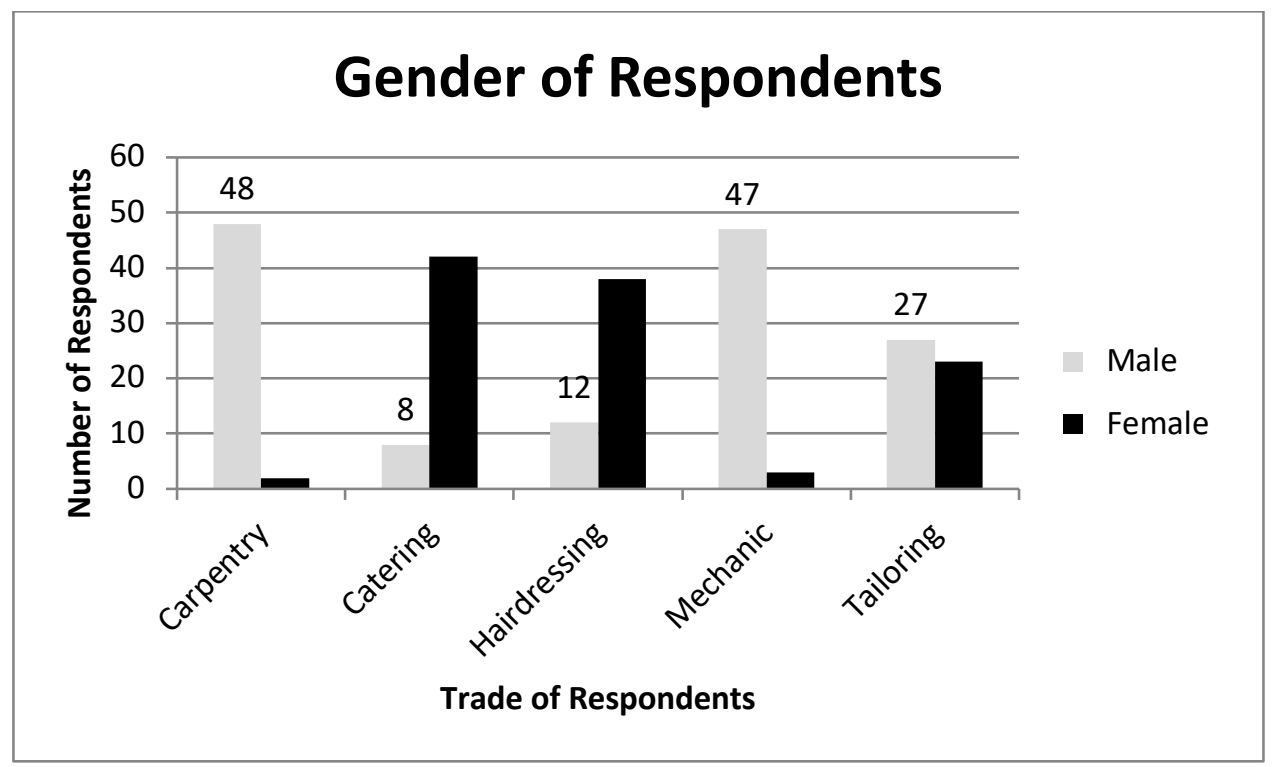

Figure 1: Gender of respondents 
Volume 2, 2020

Overall, $108(43.2 \%)$ were female and the trend showed a higher female presence in some professions as some programmes targeted women as recipients. Some skills also seemed to be more gender-specific, like Carpentry and Mechanic, which were male-dominated at $98 \%$ and $96 \%$ respectively, while Catering and Hairdressing were dominated by females at $86 \%$ and $76 \%$ (see figure 1).

Research Question One: What are the respondents' typical outputs, mode of disposal, and effect on the environment?

Responses to research question one sought to find out the respondents' typical outputs, mode of disposal, and effect on the environment. The Observation Schedule according to the trades showed, in part, their typical waste outputs as documented in Table 1. 
Table 1: Waste output and effect on the environment

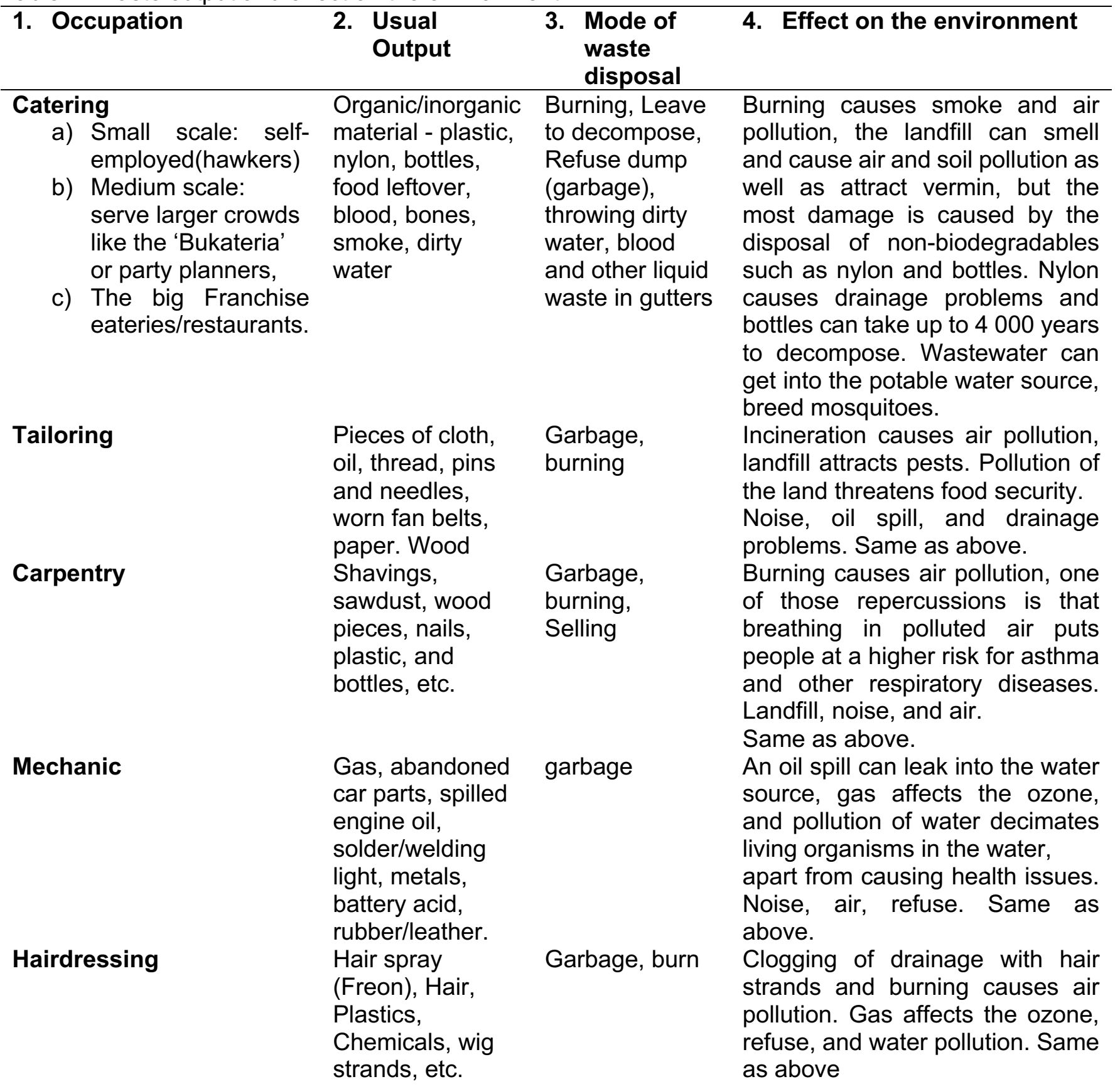


Volume 2, 2020

The table details skill sets, their typical waste output, methods of disposal, and effect on the environment. Most trades also use generators to power their activities, which adds to the noise and air pollution.

Research Question two: What are facilitators' training background and their level of incorporation of environmental awareness into skill acquisition programmes in Lagos state?

RQ2: The second research question sought the facilitators' training background and their level of incorporation of environmental awareness into skill acquisition programs in Lagos state. Figure 2 shows the educational background of the facilitators. 
Volume 2, 2020

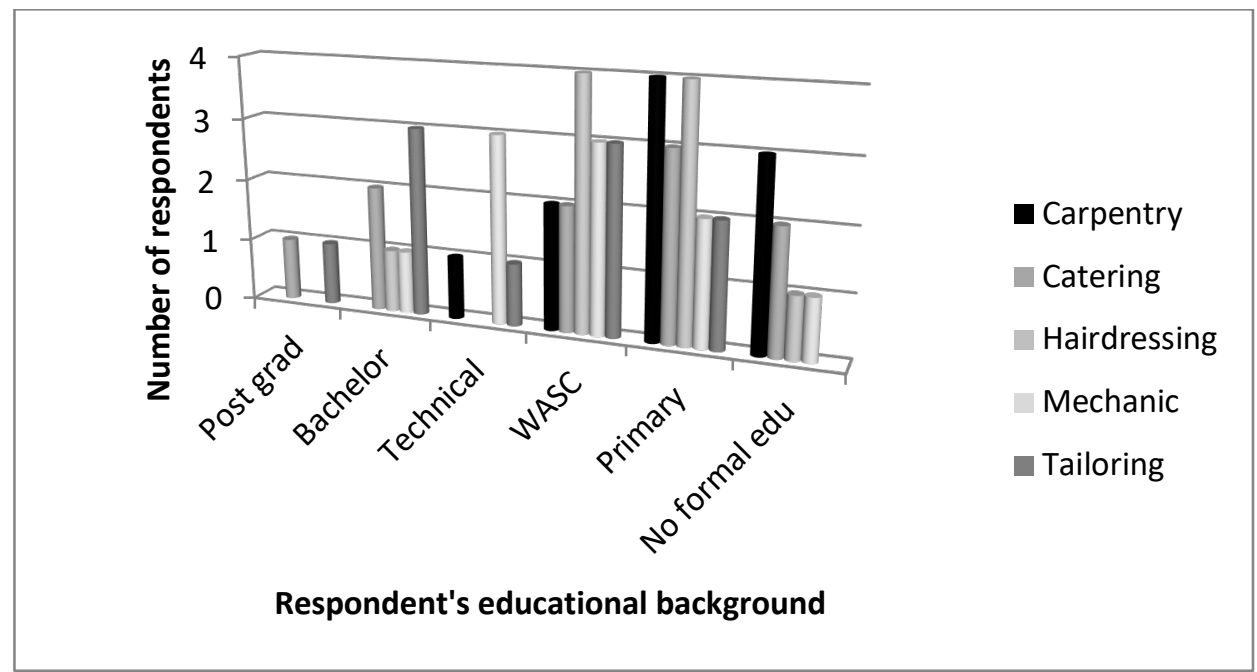

Figure 2: Facilitators' training background 
Volume 2, 2020

Facilitators' educational background revealed that, apart from formal education, hardly any facilitator was a professionally trained adult educator as none specifically had training in working with adult learners. The facilitators' training background seemed to affect their method of delivery and their incorporation of environmental awareness into skill acquisition programs in Lagos state. Responses to the Observation guide showed that facilitators were generally not found to be using andragogical principles. This oversight cannot be unconnected to Facilitators' training background. The Observation Schedule further showed that facilitators failed to use adult teaching/learning principles or methods that will allow the learners to learn experientially so that they become more invested through participatory learning about environmental care; neither were there specific courses dedicated to environmental education. This gap may be related to their lack of adult education training background. The facilitators' training background could thus be said to affect their method of delivery and the level of their incorporation of environmental awareness into skill acquisition programs in Lagos state. Facilitators' responses further addressed the lack of environmental courses when $37(74 \%)$ blamed this on the lack of provision to teach about the environment from outlined content or dedicated courses on environmental education. Facilitators generally focused more on the care of work tools/proper storage and general cleanliness. In response to a question from the Interview Schedule, one facilitator maintained ' always taught my students that cleanliness is next to godliness and that they must always keep their environments clean'. Murphy (2014) who had adopted Botha's and Atkins' theory in his study concluded that the difference in farmers' innovation adoption practices was hardly a result of socio-demographics, but rather based on the source of their information and its relevance and compatibility with farmers' needs and their capacity to adapt it into their existing farming practices. This is implied in this study that artisans will more likely adopt better environmental practices if their facilitator already incorporated it in their training. The reverse is that if the facilitators themselves were not exposed to better environmental practices in their own training, lack of vested interest in the environment would simply be perpetuated.

Research Question three: Do recipients of skill acquisition programs become more aware of their interaction with their environment as a result of their training and method used?

RQ3: Do recipients of skill acquisition programs become more aware of their responsibility to their environment as a result of their training and method used? Evidence from the observation schedule did not indicate that the respondents' behaviour towards the environment changed drastically after training. Figure 3 shows the level of incorporation of environmental education into their skill training programme.

CONTACT: Tewo V Bakare tbakare@unilag.edu.ng

This work is licensed under a Creative Commons Attribution 4.0 International License. 
Volume 2, 2020

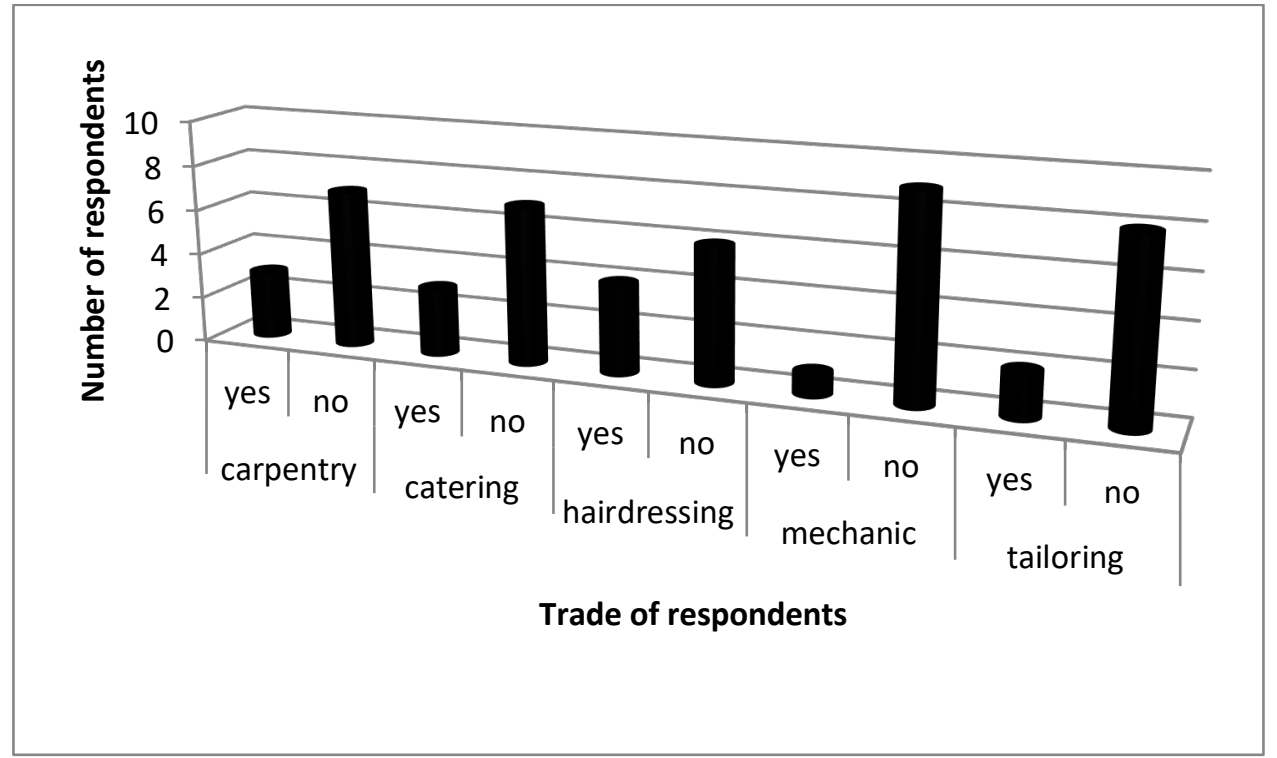

Figure 3: Facilitator's incorporation of environmental education into skill acquisition 
Volume 2, 2020

When asked whether their training affected their subsequent treatment of the environment, 181 $(72.4 \%)$ said no, $48(19.2 \%)$ responded 'mildly' while $21(8.4 \%)$ claimed to care more about their environment as indicated in table 2.

Table 2: Effect of the learners' training on their treatment of the environment

$\begin{array}{lll}\text { Yes } & \text { Mildly } & \text { No } \\ 21(8.4 \%) & 48(19.2 \%) & 181(72.4 \%)\end{array}$

Responses in Table 2 suggest that the training did not equip the learners to care better for their environment. It is possible that if a more practical and experiential method of training had been utilised, there would have been a more positive outcome. Teachers' incorporation of environmental awareness into training was found to be low at $26 \%$. Interview sessions revealed that facilitators did not learn about environmental awareness during their own training either; another respondent claimed: "nobody taught us specifically about the long-term effect of our output on the environment". This is in line with Rogers (2003:18) assertion that the informationexchange relationship determines the conditions under which a source will or will not transmit the innovation to the receiver. If the facilitators themselves were not trained in good environmental practices, they could hardly parlay any innovative ideas. Overall, the study agrees with Botha's theory of adoption.

Environmental problems identified in artisans' work locations varied from soil to air, ranging from erosion, flooding, clogged drainage, refuse dumps, noise, etc. When asked who should be responsible for solving environmental problems, the majority of $119(47.6 \%)$ of the respondents believed the government should be held responsible for environmental problems like flooding, erosion, and different forms of pollution (soil, air, etc). Their ranking of environmental problems by the artisans in their locations in order of severity showed land pollution was the highest, followed by noise and air as indicated in Table 3 .

Table 3: Ranking of the severity of environmental problems

$\begin{array}{cllll}\text { Air pollution } & \text { Land pollution } & \text { Noise pollution } & \text { Water pollution } & \text { Soil pollution } \\ 49(19.6 \%) & 81(32.4 \%) & 56(22.4 \%) & 45(18.0 \%) & 19(7.6 \%)\end{array}$

CONTACT: Tewo V Bakare tbakare@unilag.edu.ng

This work is licensed under a Creative Commons Attribution 4.0 International License. 
Volume 2, 2020

Most of the respondents $81(32.4 \%)$ felt the most severe pollution problem was in terms of refuse disposal and therefore chose land pollution. This was followed by 56 (22.4\%) who thought noise pollution ranked high too. $19.6 \%$ felt air pollution in terms of emission was a problem, while $22.4 \%$ selected noise pollution, in terms of the generator, music, traffic, and so on, and $18.0 \%$ viewed water pollution as an issue. The least was $7.6 \%$ who rated soil pollution as a problem. Most artisans (47.6\%) felt environmental problems should be resolved through government actions by government authorities and thus failed to take personal responsibility for their waste disposal activities. They felt the government should provide infrastructure like proper drainage and manage solid waste better. They all complained about the government's inability to collect waste efficiently, which leaves the onus on them to look for alternatives. Accumulated garbage causes pests, breeds mosquitoes and vermin; it equally constitutes eyesore and smell, while the run-off can affect the water source. Evidence from the Observation schedule did not indicate that the respondents' behaviour towards the environment changed after training. When asked whether their training affected their subsequent treatment of the environment $181(72.4 \%)$ said no, 48 $(19.2 \%)$ responded mildly while $21(8.4 \%)$ claimed to care more about their training as shown in Table 2.

In Summary, the level of awareness of the effect of respondents' behaviour on the environment was rather low as many did not learn environmental skills from their training. Pollution (air, soil, water) remains one of the huge contributors to environmental degradation, and facilitators spent most of their teaching time focusing on the skill acquisition process, and little, if any, on environmental matters. The extent of training on environmental care remained on keeping it clean. Awareness of the long-term effect was absent, and respondents are yet to take more responsibility for environmental management.

\section{Discussion of the Findings}

Respondents' typical output and mode of disposal negatively affect the environment (air, soil, water). Findings showed a low level of awareness of the long-term effect of their waste output on the environment by both sets of respondents. This result further highlights the effect of the gap in their training and environmental practices, which were hardly affected by training. This was found to be due to the facilitators' emphasis dwelling more on the skill acquisition itself, likely influenced by their own lack of training, which calls for heightened teacher education to enable them to resolve $21^{\text {st }}$-century problems appropriately. It also revealed a gap in the adoption of innovative and better environmental practices. Findings further showed a dearth of provision for specific courses to ensure better environmental management practices. It also indicates that not enough effort was being put into the incorporation of Environmental Education into skill acquisition programs in Lagos State, which has obviously affected artisans' adoption practices. This is in

CONTACT: Tewo V Bakare tbakare@unilag.edu.ng

This work is licensed under a Creative Commons Attribution 4.0 International License. 
Volume 2, 2020

agreement with Eneji, et al (2017) findings that not enough attention is being paid to environmental issues as yet. Facilitators' failure to incorporate environmental education into their training methods invariably exposed a lack in their own training. This is similar to Rogers' (2003:18) assertion that the information-exchange relationship determines the conditions under which a source will or will not transmit the innovation to the receiver. If the facilitators themselves were not trained in good environmental practices, they could hardly parlay any innovative ideas. Overall, the study agrees with Botha's theory of adoption.

Respondents felt it was more of the government's responsibility to care for the environment, also in line with Eneji, et al (2017). If most of their outputs wound up in the garbage, and the government does not have adequate programmes in place for its collection, there will be a problem. This exposes the wide gap that adult education can fill for all stakeholders through enlightenment and environmental awareness education so that everyone is more committed to their responsibility to the environment.

Most of the artisans' waste output contributed to environmental pollution and the gap in their training meant, understandably, their behaviour did not change significantly after their training, due to the void in environmental education. This further exposes a gap in the adoption practices as postulated by Botha and Atkins (2005). The learners have not successfully gone through the experiential process to change their behaviour towards the environment. Although Qaman (2000) agreed that in adoption studies, objective evaluations are difficult, this study agrees with Botha and Atkins' submission that communication is vital to the adoption process. When the communication process or methods teaching/learning of artisans is defective and good environmental practices are not incorporated, adoption of better environmental practices will be a non-sequitur. The typical effect of these waste by-products on the environment includes pollution of air, smell, noise, and the soil, litter, pests, contamination of water source, and loss of biodiversity. All these have an associative effect on human health, agriculture, the ozone layer, and climate change, among others; it ultimately affects socio-economic activities as well as national development efforts. The concentration on skill acquisition and the faulty resultant byproduct management constitutes a typical $21^{\text {st }}$-century problem that needs to be addressed with $21^{\text {st }}$-century solutions, like teacher's updated skill education and incorporation of technology into environmental training. The study, therefore, highlights the necessity for learners and teachers to have a shift in skill set standards and enhanced consciousness about their environment. Modernday facilitators must be suitably equipped to focus on current environmental issues and encourage its incorporation into the teaching and learning content and methods in order to be current and effective.

CONTACT: Tewo V Bakare tbakare@unilag.edu.ng

This work is licensed under a Creative Commons Attribution 4.0 International License. 
Volume 2, 2020

\section{Conclusion}

This study has indicated the need to improve awareness about environmental concerns; conscientise artisans about care for the environment and engender action to promote environmental consciousness. It has equally listed the typical output of five different artisan skills. Apart from enumerating their effect on the environment, it noted the low awareness level of the artisans from the training, calls for teacher education, and what can be done to protect the environment. Findings further showed that the level of incorporation of environmental awareness into the teaching/learning content was low, hence the need for incorporating Environmental Adult Education into the teaching-learning processes in Skill Acquisition Centres.

\section{Contribution to knowledge}

The study exposed the huge gap in the environmental training of facilitators and learners in skill acquisition programs in Lagos Nigeria. It calls attention to the adoption of innovation processes and methods that will improve environmental consciousness. It will positively contribute to the practice of environmental adult education.

\section{Recommendations}

It is important to incorporate environmental education into the content in skill acquisition programmes, no matter the mode of learning, so that learners can learn about care for the environment pari pasu the skill training. Awareness of the impact of the dire effects of their waste output and the long-term negative effect on the environment will further highlight the implications and conscientise them. It is important to dedicate courses to sustainable environmental practices to highlight environmental consciousness. Artisans must learn practices like composting and observing the three Rs - to reduce, reuse and recycle along with tree planting, etc. More than anything, it is important to properly train facilitators to approach $21^{\text {st }}$-century problems with $21^{\text {st }}$ century solutions as a matter of policy. If they were not appropriately trained, they would not know any better. Facilitators could employ appropriate methods such as Case Study, Field visits, Simulation, Excursions to disaster and model areas, and other participatory methods to engage adult learners actively in environmental education. When facilitators are aware of the effect of adoption processes of new ideas by artisans, and the need to be mindful of incorporating practical and experiential methods of synergising with the environment, they are more likely to use approaches that will maximise goal attainment and positive environmental practices. These are more engaging methods that will engender transformational teaching and learning, as well as enrich the adoption of innovation processes. The government should equally work with the populace on environmental issues; different forms of adult education can help ameliorate the

CONTACT: Tewo V Bakare tbakare@unilag.edu.ng

This work is licensed under a Creative Commons Attribution 4.0 International License. 
Volume 2, 2020

situation. Technology should also be used more to solve environmental problems and enhance distance education in line with global compliance.

\section{References}

Abia, WA., Fomboh, R., Ntungwe, E., Abia, EA., Serika, WA., \& Ageh, MT. 2016. Assessment of occupational health hazards awareness and common practices amongst barbers and hairdressers in Cameroon. Journal of Public Health in Developing Countries, 2(1): 94 - 101.

Adekeye, EA., Ojo, MO. \& Ajayi, OO. 2011. Contributions of metal welding workshops to environmental pollution in Akure metropolis, Ondo State, Nigeria. Journal of Environmental Issues and Agriculture in Developing Countries, 3(1).

Agbor, CN. 2016. The importance of incorporating environmental education into teacher education programmes in Nigeria. International Journal of Scientific Research in Education. December, 9(4): $248-263$.

Bakare, TV. 2013. Effect of coping strategies on the balancing of home and work responsibilities of the working mother in the banking sector. Lagos Education Review. Faculty of Education, University of Lagos. 13(1). January.

Bakare, TV. 2018. Ensuring sustainable environment and development: a study of solid waste management in the University of Lagos, Nigeria. African Journal of Education, Science, and Technology (AJEST). April 5 (1):114-125. Kyambogo University, Uganda; University of Eldoret, Kenya; Odumegwu Ojukwu University, Nigeria.

Bosah, VO. 2013. Environmental education in Nigeria: issues, challenges, and prospects Mediterranean Journal of Social Sciences, 4(15), November. Rome: MCSER Publishing.

Botha, N. \& Atkins, K. 2005. An assessment of five different theoretical frameworks to study the uptake of innovations. Paper presented at the 2005 NZARES conference. Tahuna Conference Centre, Nelson. New Zealand Agricultural and Resource Economics society (NZARES).

Brendia, M. 2002. Adult Education as a methodological arm of environmental adult education. Available at https://www.academia.edu/10934139/Adult Education as a Methodological Arm of Environ mental Adult Education EAE Accessed on 13 May 2019.

CONTACT: Tewo V Bakare tbakare@unilag.edu.ng

(C) $\left(\begin{array}{l}\text { (O) } \\ \text { BY }\end{array}\right.$ This work is licensed under a Creative Commons Attribution 4.0 International License. 
CEDEFOP. 2012. Green skills and environmental awareness in vocational education and training (synthesis report). European Centre for the Development of Vocational Training (Centre Européen pour le Développement de la Formation Professionnelle) Luxembourg: Publications Office of the European Union.

Eheazu, Cl. 2013. Antecedents of Environmental Adult Education. In: Eheazu, B. Barikor, C \& I. Nzeneri (eds). Readings in Adult and Non-Formal Education. Port Harcourt, University of Port Harcourt Press Ltd., 1:19-33.

Eheazu, Cl. 2016a. Situational challenges of environmental degradation in Nigeria: Adult Education as a response (University of Port Harcourt Valedictory Lecture Series, No. 6). Port Harcourt: University of Port Harcourt Press Ltd.

Eheazu. Cl. 2016b. Fundamentals of Environmental Adult Education. University of Port Harcourt Valedictory Lecture Series. Port Harcourt: University of Port Harcourt Press Ltd.).

Emms, M. 2005. The modern journeyman: Influences and controls of apprentice-style learning in culinary education. Available at https://openrepository.aut.ac.nz/bitstream/handle Accessed 22 May 2019.

Eneji, CO., Onoghen, UN., Acha, JO. 2017. Teaching Environmental Education to Adult Learners Using the Phi Delta Kappan Model in the Rural Communities of Cross River State, Nigeria. International Journal of Continuing Education and Development Studies (IJCEDS). 3(1), 80-88, April. Department of Continuing Education and Development Studies, Faculty of Education, University of Calabar, Nigeria.

Feshchuk, I. 2018. Skill Acquisition: Definition, Importance, and strategies. Available at https://jiji-blog.com/2018/11/skill-acquisition-definition-importance-and-strategies. Accessed on 10 May 2019.

Industrial Training Fund. 2014. An Appraisal of Skill Acquisition Centres in Nigeria. The Research and Curriculum Development Department. Jos: Industrial Training Fund. King, KJ. 2007. Skill acquisition in the informal sector of an African economy: the Kenya case. 108-122. https://www.tandfonline.com/doi/abs/10.1080/00220387508421528?src=recsys

Knowles, M. 1985. Andragogy in Action: Applying Modern Principles to adult learning. San Fransisco: Jossey Bass Publishers.

CONTACT: Tewo V Bakare tbakare@unilag.edu.ng

This work is licensed under a Creative Commons Attribution 4.0 International License. 
Kumar, S. 2018. Teacher's role in e-waste management and its impact on the environment. International Journal of Research in Humanities, Arts and Literature. 6(2). Impact Journals. Available at http://oaji.net/articles/2017/488-1520069223.pdf Accessed on 15 August 2020

Murphy, A. 2014. Innovation adoption and farm management practices in the Canterbury dairy industry. A Thesis in Lincoln University. Lincoln University Digital Thesis

Numbeo 2019. Pollution in Lagos, Nigeria. Available at https://www.numbeo.com/pollution/in/Lagos ret. 8/3. Accessed on 13 May 2019 Opara, PN. \& Ogudu, AA. 2009. Types of waste and their effect on the environment in Enugu state, Nigeria. Journal of Technology and education in Nigeria. 14(1-2). African Journals online JOL) https://www.ajol.info/index.php/joten/article/view/54301 Accessed 15 Sep 2020

Qamar, MK. 2000. Agricultural extension at the turn of the millennium: trends and challenges. In: Human resources in agricultural and rural development. Qamar, M.K. (ed). Ch 14.

Rogers, EM. (2003). Diffusion of innovations (5th ed.). New York, USA: Free Press.

Solaja, OM., N. Aliyu \& AO. Omobowale 2015. The dimensions of environmental pollution in lagos metropolis, Nigeria. Journal of Sustainable Development in Africa. 17(3):1 - 20. Clarion University of Pennsylvania. Clarion, Pennsylvania.

Ukemenam, OS. 2014. causes and consequences of air pollution in Nigeria. South American Journal of Public Health. 2(2).

The great schools partnership, 2020. The glossary of education reform for journalists parents and community members. Education writers association. https://www.edglossary.org/about/ Accessed 16 Sep 2020

Umunna, O. 2018. Lucrative skill acquisition programs. Career and job tips. Available at Topwritersden.com

CONTACT: Tewo V Bakare tbakare@unilag.edu.ng

(c) (9) This work is licensed under a Creative Commons Attribution 4.0 International License. 